\title{
Exploring shared leadership in public organizations: evidence from the educational arena
}

\author{
Juliana Carvalho ${ }^{1}$ \\ Filipe Sobral 1 \\ Juliana Mansur ${ }^{1}$ \\ ${ }^{1}$ Fundação Getulio Vargas (FGV EBAPE) / Escola Brasileira de Administração Pública e de Empresas, Rio de Janeiro / RJ - Brazil
}

\begin{abstract}
Collective leadership, reflecting the representative and participatory character of bureaucracies, is known to have a good fit for public organizations. Despite the importance of the topic, very few studies have examined what triggers the emergence of shared or participative leadership in public organizations and how these plural forms of leadership translate into team outcomes. To fill this gap, this study explores whether the existence of an organizational climate characterized by participative safety (a climate characterized by shared purpose, social support, and voice) can facilitate the emergence of collective forms of leadership, such as shared leadership. Further, we investigate if shared leadership ultimately influences an important organizational outcome: voluntary turnover. To test our model, we conducted a field study with 96 public schools and more than 1,000 teachers of the public educational system of the city of Rio de Janeiro. Our results highlight the importance of the existence of a favorable organizational climate for the emergence of shared leadership and provide evidence of the positive effects of this type of leadership on reducing turnover ratings among public teachers.
\end{abstract}

Keywords: shared leadership; public leadership; organizational climate; turnover; public education.

\section{Explorando a liderança compartilhada em organizações públicas: evidências da arena educacional}

A liderança coletiva, que reflete o caráter representativo e participativo das burocracias públicas, é reconhecida como um bom modelo para este tipo de organizações. No entanto, apesar da importância do tópico, poucos estudos exploraram o que promove a emergência da liderança compartilhada ou participativa em organizações públicas e como essas formas plurais de liderança se traduzem em resultados organizacionais. Para preencher essa lacuna, exploramos como a existência de um clima organizacional caracterizado pela segurança participativa (um clima marcado por propósito compartilhado, apoio social e voz) pode facilitar o de estilos de coletivos de liderança, como a liderança compartilhada. Além disso, investigamos se a liderança pode impactar um importante indicador organizacional: rotatividade. Para testar nosso modelo, realizamos um estudo de campo com 96 escolas públicas e mais de 1.000 professores da rede pública de ensino da cidade do Rio de Janeiro. Nossos resultados ressaltam a importância da existência de um clima organizacional favorável ao surgimento de liderança compartilhada e evidencia os efeitos positivos desse tipo de liderança na redução dos índices de rotatividade de profissionais da rede pública.

Palavras-chave: liderança compartilhada; liderança pública; clima organizacional; rotatividade; educação pública.

\section{Explorando el liderazgo compartido en las organizaciones públicas: evidencias de la arena educativa}

El liderazgo compartido, que refleja el carácter representativo y participativo de las organizaciones públicas, es reconocido por su adecuación a este tipo de burocracia. Sin embargo, a pesar de la importancia del tema, pocos son los estudios han examinado qué desencadena la aparición del liderazgo compartido o participativo en las organizaciones públicas y cómo estas formas plurales de liderazgo se traducen en resultados organizacionales. Para llenar esta brecha, exploramos cómo la existencia de un clima organizacional caracterizado por la seguridad participativa (un clima determinado por propósito compartido, apoyo social y voz) puede facilitar estilos de colectivos de liderazgo, como el liderazgo compartido. Además, investigamos si el liderazgo puede tener impacto sobre un importante indicador organizacional: rotación de personal. Para probar nuestro modelo, realizamos un estudio de campo con 96 escuelas públicas y más de 1.000 profesores de la red pública de enseñanza de la ciudad de Río de Janeiro. Nuestros resultados resaltan la importancia de la existencia de un clima organizacional favorable al surgimiento del liderazgo compartido y evidencia los efectos positivos de ese tipo de liderazgo en la reducción de los índices de rotación de profesionales de la red pública.

Palabras clave: liderazgo compartido; liderazgo público; clima organizacional; rotación de personal; educación pública. 


\section{INTRODUCTION}

The Public Administration (PA) literature has been highlighting the role of leadership in the public sphere (e.g., Jesper \& Villadsen, 2010; O’Toole \& Meier, 2015; Park \& Rainey, 2008). Scholarly research has focused on investigating the effects of leadership on the attitudes and behaviors of public servants and, importantly, on job performance (Getha-Taylor et al., 2011; Van Slyke \& Alexander, 2006; Van Wart, 2013; Vogel \& Masal, 2015). However, most of the existent literature have adopted a hierarchical and vertical approach to leadership, disregarding the integrative and participative nature of the public administration domain (Huxham \& Vangen, 2005; Jesper \& Villadsen, 2010)

The need for collaborative leadership and participative forms of management emerges from the foundations of democracy and the need for representation in public bureaucracies (Getha-Taylor et al., 2011). Therefore, sharing decision making and control enables team members to assume a more participative role that allows the public machine to work more effectively (Van Wart, 2013). Previous research has shown that collaborative and shared forms of leadership are suitable for most governmental institutions, especially in the health, education, and project management settings (Currie \& Lockett, 2011; Currie, Koteyko, \& Nerlich, 2009; Ospina, 2017; White, Currie, \& Lockett, 2016). Since these settings comprise a range of knowledge-based organizations, which are characterized by high task complexity and qualified employees, public servants are more likely to take leadership roles and responsibilities (Denis et al., 2012; Pearce \& Manz, 2005).

Previous research in PA has shown the impact of shared leadership on performance indicators, such as productivity, commitment, innovation, and service performance (Lacerenza \& Salas, 2017; Fitzgerald, Ferlie, McGivern, \& Buchanan, 2013) and how the institutional structure can affect the dynamics of distributed leadership (Currie et al., 2009). However, few studies have empirically examined which team characteristics can help plural forms of leadership to flourish. Specifically, to our knowledge, no studies have yet explored the role of participative safety as a facilitator of the emergence of shared leadership in public organizations.

To address this gap in research, we examine how a positive internal team environment, characterized by shared purpose, social support, and voice, known as participative safety (Serban \& Roberts, 2016), can facilitate the emergence of shared leadership in a public context. Further, we also explore the effects of shared leadership in reducing voluntary turnover rates among teachers. To test our predictions, we conducted a field study with 96 public schools and more than 1,000 teachers of the public educational system of the city of Rio de Janeiro.

By examining the antecedents and consequences of shared leadership in the Public sector, we believe in contributing to the public leadership literature and practice in three significant ways. First, we explore an antecedent that enables shared leadership to emerge. Second, we empirically test the effects of shared leadership on school outcomes, specifically teachers' voluntary turnover. Finally, we contribute to practice by showing that sharing leadership can be an effective way to cope with familiar public managers' dilemmas, such as representation and democracy in governmental settings. 


\section{THEORETICAL BACKGROUND}

\subsection{Public Administration and Leadership}

The study of leadership has always been a topic explored by PA scholars, as effective leadership is associated with good governance (Van Wart, 2013). However, the widespread of reforms in the late 1980s entailed greater responsibilities and autonomy to senior offices, making their roles even more central to public bureaucracies. These reforms forced a change in bureaucracy heads, from only being managers (meaning the ones that generate order and efficiency), to assume the roles of leaders (producing change and movement, by influencing others) (Kotter, 1990). Such a shift of perspective has fostered the emergence of leadership studies in the field of Public Administration (Van Wart, 2013).

However, a fundamental issue when we talk about leadership in governmental settings is to think about how the characteristics of the public sphere require unique needs of their leaders, shaping their actions and characteristics (Chapman et al., 2016; Getha-Taylor et al., 2011; Van Wart, 2013; Vogel \& Masal, 2015). For example, as pointed by Perry and Rainey (1988), while private institutions are privately owned, public ones are collectively owned by the community they serve, which finance their actions through taxes and has an essential influence on organizational actions (Hvidman \& Andersen, 2014; Meier \& O’Toole, 2015).

Also, public companies deal with intangible, symbolic, multiple, and challenging to measure goals that must respect principles such as democracy, justice, responsiveness, social equity, openness, accountability, and moral correctness. Often, some of these goals are conflicting and strongly influenced by political actors and public scrutiny (Currie et al., 2009; Rainey, 2003). Differences in human capital are also an important distinction between public and private administration. Government agencies often have elaborated administrative structures that make management more complex and overburden staff with excessive red tape (Rainey, 2003; Van Wart, 2013). Further, public leaders do not have complete freedom to hire and fire their employees, and there are few extrinsic motivators to stimulate the work of public servants (e.g., raises, bonuses, and promotions).

Moreover, public workers have many behavioral characteristics that are different from those that operate in private companies, such as a higher sense of identification with organizational missions and greater intrinsic motivation (Bullock, Stritch, \& Rainey, 2015; Chapman et al., 2016; Park \& Rainey, 2008; Perry \& Rainey, 1988). Finally, the constant influence of politicians and the existence of institutional constraints also influence decision making in these bureaucracies, which impacts their effectiveness (Hvidman \& Andersen, 2014; Van Slyke \& Alexander, 2006). Despite the stability among public servants, there is a high level of turnover among political appointees due to changes across different mandates (Bullock et al., 2015; Rainey, 2003), which may ultimately affect performance.

Because of the characteristics mentioned above, some leadership practices may be better suited to the public context. Transformational leadership, for example, has been suggested as a good option for government agencies as it enhances two critical aspects of the nature of such organizations: mission valance and goal clarity, both of which impact important outcomes such as performance, satisfaction, and motivation (Wright \& Pandey, 2010; Wright, Pandey, \& Donald, 2012) 
However, since democratic inclusion and pluralism are vital features of public administration, a collective style of leadership may have an even better fit for this type of organization, as leadership distribution better reflects the integrative and participatory character of government bureaucracies (Getha-Taylor et al., 2011). As such, we argue that the process of sharing leadership can be a more appropriate way of achieving the essential goals of the public leader (e.g., serving the public interest, promoting democratic and ethical) than vertical and hierarchical processes of leadership (Currie et al., 2011; Denis et al., 2012; Van Wart, 2011). In the next session, we will discuss the characteristics of shared leadership and its benefits to PA.

\subsection{Shared Leadership and Public Administration}

Most leadership research focuses on the role of an individual leader, on whom much of the organizational expectations are relying on (Sobral \& Furtado, 2019; Yukl, 2002). However, many authors have emphasized that it is very difficult for a single person to possess all the characteristics and skills necessary for effective leadership, an issue that has become even harder nowadays, with the increasing complexity of organizations and the need to adapt to constant changes (D'Innocenzo, Mathieu, \& Kukenberger, 2016; Kocolowski, 2010). Also, many contemporary approaches of leadership have focused on the relational perspective of leadership, perceiving it as a non-hierarchical practice that is distributed across the organization (Cunliffe \& Eriksen, 2011). Therefore, having a horizontal leadership process that counts on plural leaders with different skills and abilities can be an effective way to cope with the dilemmas of contemporary organizations (Kocolowski, 2010; Van Wart, 2013).

Shared leadership (sometimes interchangeably called distributed, horizontal, or plural leadership) can be understood as a collectivist process, in which multiple people assume leadership roles, both formally and informally (Van Wart, 2013; White et al., 2016; Yammarino, Salas, Serban, Shirreffs, \& Shuffler, 2012). In such a process, the leadership responsibility is divided between individuals according to their unique competencies. The combination of different expertise can create a stronger type of leadership, based on sharing knowledge and competencies (Lacerenza \& Salas, 2017; Van Wart, 2013). In this collectivist perspective, leadership is not only a style or a set of individual actions and characteristics but rather a process of influence among two or more individuals, leading and influencing one another, towards the achievement of a common goal (Lacerenza \& Salas, 2017; Ospina, 2017; Pearce \& Conger, 2002)

Complex, knowledge-based organizations, with highly skilled professionals are the adequate ones for the development of shared leadership, as these individuals usually prefer to work independently in an integrated form (Kocolowski, 2010; Lacerenza \& Salas, 2017; Pearce, 2004). In this context, sharing leadership is critical, as it is tough for a single leader to have all the knowledge and skills required to lead different work specialties (Pearce, 2004; Pearce \& Manz, 2005).

Due to these specific conditions, previous research has generally found stronger effects of plural forms of leadership on top management teams (Mihalache, Jansen, Van den Bosch, \& Volberda, 2014), volunteers (Routhieaux, 2015); virtual teams (Drescher et al., 2014) and research and development teams (Fausing, Joensson, Lewandowski, \& Bligh, 2015). In the field of Public Administration, research has mainly focused on schools and hospitals (Currie et al., 2011; Currie et al., 2009; Currie \& Lockett, 2007; Ospina, 2017; Pearce, Wood, \& Wassenaar, 2018; White et al., 2016). 
Specifically, in the field of education, more than 200 papers on shared leadership have been published between 1980 and 2014 (Gumus, Bellibas, Esen, \& Gumus, 2018). Despite the theoretical nature of most of these studies, empirical research indicates the impact of the distribution of leadership on teachers' self-efficacy (MacBeath, 2005), teaching quality (Little, 1990), organizational development and change (Hallinger, 2011; Leithwood et al., 2008) and students' outcomes (Hallinger \& Heck, 2010). Regarding the effects on individual level-outcomes, previous research indicates its impact on commitment (Akbari, Kashani, \& Hooshmand Chaijani, 2016), performance (Carson, Tesluk, \& Marrone, 2007; Drescher \& Garbers, 2016; Fausing et al., 2015), cohesion (Bergman et al., 2012 ) and trust (Bergman et al., 2012; Boies, Lvina, \& Martens, 2011).

Indeed, as participation increases, so does the individual motivation to contribute with a goal, which enhances team cohesion, impacting results. Moreover, collaboration leads to better coordination and efficiency, thereby increasing overall performance (Bergman et al., 2012; Boies et al., 2011; Carson et al., 2007; Pearce, 2007). Nevertheless, despite the positive effects on organizational and team outcomes, the distribution of leadership can also be an action that helps public leaders to deal with the complexity of current public agendas (Ospina, 2017), guaranteeing democratic inclusion and pluralism in public bureaucracies (Currie et al., 2009).

In Brazil, the literature on shared leadership is scarce. Nevertheless, the few studies conducted, such as Amestoy et al. (2014), Dall'Agnol (2013) and Braun and Fagundes (2017), point to shared leadership as a way to develop more consistent management practices, thus promoting a more integrated and satisfactory work environment for team members. In this matter, it is essential to point that shared leadership is a process that emerges from the interaction between individuals. Therefore, some conditions can facilitate or even constrain the distribution of leadership, which we will discuss in the next section.

\section{FRAMEWORK AND HYPOTHESES}

Most research on shared leadership focuses on its importance and impact on outcomes. However, the conditions that facilitate the emergence of plural leaders or plural forms of leadership are less studied, thus lacking theoretical and empirical evidence on the conditions that facilitate the emergence of shared leadership. In the present work, our focus is on investigating an antecedent that allows shared leadership to emerge and its impacts on organizational performance. Based on the input-processoutcome theoretical framework (I-P-O framework; McGrath, 1964), we explore the impact of a given process on an outcome, as well as the conditions that allow the process to occur.

According to the I-P-O framework, team outcomes (such as performance, satisfaction, or turnover) result from team interactions toward a specific goal. In our case, shared leadership is considered the result of team interaction towards goal achievement, which, in turn, decreases turnover rates. In the I-P-O framework, the relationship between the team's behaviors and the turnover outcome represents the so-called process to output. However, as recognized previously by the literature, different factors can facilitate or constrain the interaction of group members, which are called inputs or antecedents (Mathieu, Maynard, Rapp, \& Gilson, 2008). Thus, to understand the results of the group processes, this framework considers three stages: the inputs, the process, and the outcomes.

Unlike processes, which emerge from relationships between people, inputs are qualities and characteristics of the organizational environment, the team or individuals, which do not necessarily 
depend on the joint action of individuals (Mathieu et al., 2008). Although there are different types of inputs, our focus will be on inputs that Marks, Mathieu, \& Zaccaro (2001) call emerging team states. These are variables that represent attitudes, values, cognition, and motivators of the workgroup or organization, such as effectiveness or commitment. In the case of shared leadership, Currie et al. (2009) argue that a formal leader will only resign his or her role when there is a positive, collaborative and trustful climate between the team members. Similarly, Fletcher and Kaufer (2003) point out that a climate characterized by trust and empathy between team members is a necessary condition for the emergence of shared leadership. Thus, we also explore the effects of having a climate of participation and safety in the distribution of leadership.

The concept of Participative Safety was coined by Anderson and West (1996), as a factor that facilitates team development and performance, as teams are able to improve when they feel comfortable with one another (Fairchild \& Hunter, 2014). The construct is composed of two dimensions: security and participation. On the one hand, intragroup safety refers to having a non-threatening environment to manifest ideas, characterized by mutual support and trust (Peltokorpi \& Hasu, 2014). On the other, intragroup participation refers to participation in the decision-making process, as individuals feel encouraged to share and listen to others' ideas (Fairchild \& Hunter, 2014; Peltokorpi \& Hasu, 2014).

The existence of a participative and safe environment allows team members to contribute with more ideas, improving discussions continuously, and work processes (Bradley et al., 2012). Also, the psychological feeling of being free to act without censorship or interpersonal consequences can enhance one's willingness to seek more responsibility in their work, and thus take on informal leadership roles. Based on these arguments, we propose that:

\section{H1: A participative safe environment positively influences the emergence of shared leadership.}

As pointed by previous research, the process of shared leadership that will emerge from a climate of trust and participation can affect not only organizational outcomes but also affect individual attitudes and behaviors, enhancing engagement and job satisfaction (Kocolowski, 2010). We focus on investigating the effect of shared leadership on a behavioral indicator of job satisfaction, which is voluntary turnover. Employee turnover - understood here as the employee's voluntary decision to leave the not only negatively affects the company, but it also affects every individual on the team, directly impacting their motivation and commitment (Hom, Lee, Shaw, \& Hausknecht, 2017).

Indeed, a vast body of empirical research shows the negative relationship between these variables suggesting that job satisfaction predicts voluntary turnover, as workers who experience unfavorable working conditions are more likely to have a decrease in performance, seek another job and, finally, resign. Previous research indicates that the lack of one's job satisfaction can be due to a decrease in extrinsic motivation (hygiene factors, such as monetary rewards) and intrinsic motivation (motivational factors, such as positive work climate, job autonomy, or professional development) (Ambiable, 1993).

Examining Brazilian public servants' motivational factors, we observe that these professionals have a high level of extrinsic motivation, which is the result of high salaries (which surpass the private sector 
by $84 \%^{1}$ ), lifelong job stability, and several other benefits extended to servants' family. Conversely, intrinsic motivational factors, such as work climate, leadership, and participation in decision making, are generally indicated as causes to job rotation among Brazilian public servants (Klein \& Mascarenhas, 2016). Based on such pieces of evidence, we believe that the existence of a collaborative process of leadership can be a determining factor in one's decision to stay in the organization by increasing their intrinsic motivation. Thus, we propose:

$\mathrm{H} 2$ : The existence of shared leadership negatively influences turnover rates; that is, sharing leadership contributes to reducing turnover.

In sum, according to our I-P-O framework, we examine the effect of Participative Safety, our input, on the Shared Leadership process, which in turn impacts turnover, our outcome of interest.

\section{METHODS}

\subsection{The Brazilian Context}

Contemporary public administration in Brazil enacts a broad array of practices that vary from traditional bureaucratic models to more updated governance ideal-types (Peci, Pieranti, \& Rodrigues, 2008). The mix of models, influenced by core features of the national character (such as authoritarianism, paternalism, patrimonialism and coronelismo), originated a unique model, which Zwick, Teixeira, Pereira, and Vilas Boas, (2012) called “Tupiniquim Public Administration." Due to the influence of diverse and even conflicting perspectives, the Brazilian organizational context is often marked by contrasts, such as participation and high levels of control.

Looking specifically at Educational Management models in Brazil, the model of Democratic Participation is mostly adopted by Brazilian schools. Such a model implies dynamic management practices that need to be flexible and suited to the specific context the school is in. Likewise, educational practices must be based on collaboration, as the responsibility for organizing and managing schools is shared by all individuals that compose the educational community (Passone, 2019; Lima, 2014). Thus, despite the particularities of the Brazilian Public Administration, and the limitations that the Tupiniquim model can impose on schools, the management model officially adopted by Brazilian schools is based on participation and collaboration, which make the educational arena a favorable space for the development of shared leadership.

\subsection{Organizational Context}

This study will analyze the antecedents and effects of shared leadership in public school systems in the municipality of Rio de Janeiro, the largest public school system in Latin America, with 1,537 schools, 654,949 students, 41,216 teachers, and 14,963 school bureaucrats (Secretaria Municipal de

\footnotetext{
${ }^{1}$ According to data from the Departamento Intersindical de Estatística e Estudos Socioeconômicos (2018).
} 
Educação da Cidade do Rio de Janeiro, 2017). Such a system offers universal education for the first nine years of elementary education (1st to 9th grade), as well as classes in early childhood education and adult education. Like all Brazilian public schools, they are tuition-free institutions, and employees are admitted by public tender. Bureaucrats, responsible for secretarial activities and teachers, make up the school staff.

The management of the school is the responsibility of the management team, composed of the director, deputy director, and pedagogical coordinator. Such individuals are part of the faculty of the school and are elected by the school community to fill these positions. They have the autonomy to set instructional plans for the school year, following established the minimum prerequisites, accept and transfer students, and manage part of the school budget that is reserved for improvements. However, one significant limitation is that they do not have the freedom to hire or fire personnel.

The use of these schools as a sample offered us three main advantages. First, all units that offer basic education follow the same school curriculum, and students are submitted to the same standardized tests; therefore, the outcomes are comparable. Second, as Rio is a large city with diverse regions, we have the presence of different minorities and representative contexts. However, due to these variations, some aspects such as region demographics and school size should be controlled for. Finally, as the study is a partnership with the municipal office of education, we will be able to access leaders and subordinates simultaneously.

\subsection{Sample and procedures}

In order to guarantee the representation of different types of schools and regions of the city, our sample was selected using the probabilistic approach of stratified sampling. First, our population was divided into the 11 geographic regions that the system of education of Rio de Janeiro is divided into. Within each group, schools were separated into four subgroups according to their size and HDI (Human Development Index) of the region. Schools were randomly chosen from each group, according to their proportion in that geographic area. After randomly selecting the participant schools, a posthoc analysis was made to guarantee that schools also represented the population in approval rates, standardized test grades, and the number of teachers. In our final sample, totalizing 163 schools, all 11 regions had equal representation in the population of schools in the municipality.

Teachers, principals, vice-principals, and pedagogical coordinators from 151 schools responded to our survey, totalizing 1.372 participants. However, as data were analyzed at the school level, we could only analyze schools that had responses from the principal, the vice-principal or the counselor (the management team), and at least two teachers. Due to such criteria, our final sample had a total of 96 schools and 1,004 participants. Table 1 describes the characteristics of the schools in the population and our final sample. 


\begin{tabular}{lcc}
\hline Characteristics & Sample Average & Population Average \\
\hline \# students & 628 & 598 \\
\# of classes & 22 & 21 \\
\# of teachers & 28 & 26 \\
Total Employees & 51 & 48 \\
HDI & 3 & 3 \\
School Complexity & 3 & 3 \\
Retention Rate $^{3}$ & $91 \%$ & $92 \%$
\end{tabular}

Source: Elaborated by the authors.

\subsection{Measures}

Shared Leadership was measured using the 4-item scale adapted from Wahlstrom and Louis (2008).On a 5 -point Likert scale ( $1=$ "strongly disagree" to $5=$ "strongly agree"), participants were asked to answer items such as: "Teachers have an effective role in the school-wide decision making." We averaged teachers' responses to the items to form a school perception of shared leadership ( $\alpha=$ $\left.0.93 ; \mathrm{r}_{\mathrm{WG}}=0.64 ; \operatorname{ICC}(1)=0.21 ; \operatorname{ICC}(2)=0.57\right)$.

Participative Safety was measured using the 8 -item scale developed by Anderson and West (1996). A sample item is "We generally share information in the team, rather than keeping it to ourselves." The measure is averaged across school staff (managerial team and teachers), that answered their perceptions in a 5-point Likert scale ( 1 = "strongly disagree" to $5=$ "strongly agree") $\left(\alpha=0.93 ; \mathrm{r}_{\mathrm{WG}}=\right.$ 0.83 ; $\operatorname{ICC}(1)=0.12 ; \operatorname{ICC}(2)=0.42)$.

Turnover was obtained through secondary data, which informed the number of servants that were either transferred to other schools or the regional office. We have considered the transference rate as a measure of turnover as public servants in Brazil have tenure until retirement, which implicates in a shallow rate related to actual turnover. Nevertheless, asking for transference indicates the desire to leave that specific school.

Previous research has shown that controlling for contextual factors, such as violence and socioeconomic indicators or the region a school is located, is essential for coping with neighborhood effects (Coeli \& Green, 2012). We have also included controls for the school and class complexity, as these variables might affect both organizational climate and the complexity of teaching and managing in a given school. The description of each control is below:

Social Economic Indicator is the socioeconomic indicator based on the individual data of the students, considering the possession of consumer goods, characteristics of their homes, parents' schooling level, and frequency of hiring domestic services. The official index is calculated by INEP (National Institute of Educational Studies and Research Anísio Teixeira), and it is aggregated at the school level, ranging from 1 (very low) to 7 (very high).

\footnotetext{
${ }^{2}$ An index created by the Brazilian Ministry of Education that indicates the complexity of managing a given school.

${ }^{3}$ Percentage of students who move on for the next school year.
} 
School Complexity is an official index that calculates the complexity of school management according to 4 characteristics: (1) school size; (2) the number of teaching stages offered (3) complexity of the stages offered, (4) the number of shifts offered. The scale, created by INEP, and ranges from 1 to 6 .

Number of Students per Teacher is proxy to class size, considered to be a key indicator for education quality and teacher effort.

Violence Index is the total number of homicides that occurred up to 500 meters from the school, between 2014 and 2016.

\section{RESULTS}

\subsection{Confirmatory Factor Analysis}

In the first stage of the data analysis, a CFA using the maximum-likelihood method was applied to test the fit of the proposed two-factor model. When running the model with covariances between the variables, results suggested a good fit $(\mathrm{CFI}=0.97$; $\mathrm{TLI}=0.96$; $\mathrm{RMSEA}=0.07)$. Also, an alternative model in which all items were loaded into a single factor exhibited worse fit $(\mathrm{CFI}=0.71$; $\mathrm{TLI}=0.64$; RMSEA = 0.22), providing further evidence to support our proposed model.

Loadings were above the recommended threshold of 0.5 (Hair et al., 2010). Also, the squared correlation between constructs is smaller than the AVEs of these constructs (Fornell \& Larcker, 1981), which also indicates convergent validity.

The composite reliabilities were above the minimum cut off at 0.60 (Bagozzi \&Yi, 1988), which indicates propper reliability of the variables. AVEs, indicators of discriminant validity, crossed the minimum threshold of 0.5 (Fornell \& Larcker, 1981). Table 2 shows factor loadings, AVE, and CR for the constructs.

\section{TABLE 2 FACTOR LOADINGS, COMPOSITE RELIABILITY, AND AVE}

\begin{tabular}{|c|c|c|c|c|}
\hline Variable & Item & Loading & CR & AVE \\
\hline \multirow{4}{*}{ Shared Leadership } & Shared_Leadership 1 & 0.82 & \multirow{4}{*}{0.93} & \multirow{4}{*}{0.78} \\
\hline & Shared_Leadership 2 & 0.95 & & \\
\hline & Shared_Leadership 3 & 0.80 & & \\
\hline & Shared_Leadership 4 & 0.94 & & \\
\hline \multirow{8}{*}{ Participative Safety } & Participative_Safety 1 & 0.77 & \multirow{8}{*}{0.93} & \multirow{8}{*}{0.61} \\
\hline & Participative_Safety 2 & 0.85 & & \\
\hline & Participative_Safety 3 & 0.72 & & \\
\hline & Participative_Safety 4 & 0.80 & & \\
\hline & Participative_Safety 5 & 0.74 & & \\
\hline & Participative_Safety 6 & 0.75 & & \\
\hline & Participative_Safety 7 & 0.80 & & \\
\hline & Participative_Safety 8 & 0.82 & & \\
\hline
\end{tabular}

Source: Elaborated by the authors. 
Table 3 presents the means, standard deviations, and the correlations between the variables of the study. These results show that, in the period of analysis, an average of 3 teachers asked to leave their place of work, which represents a turnover level of $11 \%$. We should also note that, on average, students presented relatively low socioeconomic status (3.39, on a scale ranging from 1 to 7 ). The ratio of students per teacher was, on average, 22.38, and between 2014 and 2016, an average of 3.42 homicides occurred up to 500 meters from the schools.

TABLE 3 MEANS, STANDARD DEVIATIONS AND CORRELATIONS MATRIX FOR STUDY VARIABLES $(\mathrm{N}=96)$

\begin{tabular}{|c|c|c|c|c|c|c|c|c|c|}
\hline & Mean & S.D. & 1 & 2 & 3 & 4 & 5 & 6 & 7 \\
\hline Turnover (1) & 3.03 & 1.72 & 1 & & & & & & \\
\hline Participative Safety (2) & 4.00 & 0.39 & -0.12 & 1 & & & & & \\
\hline Shared Leadership (3) & 4.06 & 0.70 & $-0.35^{+*+x}$ & $0.43^{* \cdots}$ & 1 & & & & \\
\hline Violence Index (4) & 3.42 & 2.90 & 0.02 & -0.17 & -0.10 & 1 & & & \\
\hline Social Economic Indicator (5) & 3.39 & 0.49 & -0.17 & 0.07 & 0.10 & -0.11 & 1 & & \\
\hline School Complexity (6) & 3.38 & 1.2 & $0.24^{*}$ & $-0.25^{*}$ & $-0.21^{*}$ & $-0.25^{*}$ & -0.17 & 1 & \\
\hline Students/Teacher (7) & 22.58 & 5.17 & -0.05 & -0.14 & 0.02 & -0.01 & -0.10 & $0.28^{* *}$ & 1 \\
\hline
\end{tabular}

${ }^{*} p<0.05,{ }^{* *} p<0.01,{ }^{* * *} p<0.001$

Source: Elaborated by the authors.

\subsection{Hypothesis Testing}

As reported in table 4, five different models were estimated to test our hypothesis. Models 1 and 2 estimate the direct effects of the control variables and Participative Safety on Shared Leadership. While models 3, 4, and 5 test the effects of all variables of interest in the dependent variable Turnover. To test our first hypothesis, that states the significant impact of Participative Safety on Shared Leadership; we conducted multiple regression analysis. As reported in Model 2 of Table 4, results showed that there is a significant direct effect of Participative Safety on Shared Leadership $(b=0.71, p<0.001)$, which supports Hypothesis 1.

In another multiple regression, we have estimated the effects of Shared Leadership on Turnover. As we can see in Model 5 of Table 4, there is a significant negative effect of Shared Leadership in Turnover $(b=-0.80 ; p<0.05)$, which means that the leadership distribution among employees decreases school exit requests, thus supporting Hypothesis 2. 
TABLE 4

RESULTS

\begin{tabular}{|c|c|c|}
\hline & \multicolumn{2}{|c|}{ DV: Shared Leadership } \\
\hline & Model 1 & Model 2 \\
\hline \multirow[t]{2}{*}{ Violence Index } & -0.04 & -0.02 \\
\hline & $(0.03)$ & $(0.02)$ \\
\hline \multirow[t]{2}{*}{ Social Economic Indicator } & 0.06 & 0.07 \\
\hline & $(0.15)$ & $(0.14)$ \\
\hline \multirow[t]{2}{*}{ School Complexity } & $-0.15^{\star}$ & -0.08 \\
\hline & $(0.06)$ & $(0.06)$ \\
\hline \multirow[t]{2}{*}{ Students/Teacher } & 0.01 & 0.01 \\
\hline & $(0.02)$ & $(0.01)$ \\
\hline \multirow[t]{2}{*}{ Participative Safety } & & $0.71^{* * *}$ \\
\hline & & $(0.18)$ \\
\hline \multicolumn{3}{|l|}{ Shared Leadership } \\
\hline \multirow[t]{2}{*}{ Constant } & $4.25^{*+*}$ & 1.05 \\
\hline & $(0.68)$ & $(1.01)$ \\
\hline N & 96 & 96 \\
\hline R2 & 0.08 & 0.22 \\
\hline $\mathrm{F}$ & 1.86 & 5.00 \\
\hline
\end{tabular}

\begin{tabular}{cccc}
\hline & DV: Turnover & \\
Model 3 & Model 4 & Model 5 \\
0.07 & 0.07 & 0.06 \\
$(0.06)$ & $(0.06)$ & $(0.06)$ \\
-0.46 & -0.46 & -0.40 \\
$(0.35)$ & $(0.35)$ & $(0.34)$ \\
$0.44^{* *}$ & $0.43^{* *}$ & $0.36^{*}$ \\
$(0.15)$ & $(0.16)$ & $(0.15)$ \\
-0.07 & -0.07 & -0.05 \\
$(0.04)$ & $(0.035)$ & $(0.03)$ \\
& -0.14 & 0.42 \\
& $(0.45)$ & $(0.46)$ \\
& & $-0.80^{* *}$ \\
& & $(0.26)$ \\
$4.30^{* *}$ & 4.94 & $5.77^{*}$ \\
$(1.59)$ & $(2.58)$ & $(2.48)$ \\
96 & 96 & 96 \\
0.13 & 0.13 & 0.21 \\
3.31 & 2.64 & 4.00 \\
\end{tabular}

Standard errors in parentheses

${ }^{*} p<0.05,{ }^{* *} p<0.01,{ }^{* * *} p<0.001$

Source: Elaborated by the authors.

An I-P-O process proposes that a specific input, in our case, a variable of climate (i.e., Participative Safety), creates conditions that enable the development of interactions within a team, leading to the emergence of a process (i.e., Shared Leadership). Finally, this emergent process affects a given outcome (i.e., turnover). When looking at the whole I-P-O framework, we could understand it as mediation, in which the process mediates the relationship between the input and the output. To test this theory, we ran an additional analysis to investigate if Shared Leadership mediates the relationship between Participative Safety and Turnover.

Results of a Sobel test indicated significant effects of Participative Safety on Shared Leadership $(b=0.71 ; p<0.001)$ and a significant effect of the leadership on Turnover $(b=-0.80 ; p<0.01)$. We did not find a direct effect of Participative Safety on Turnover $(b=0.42 ; p=n$.s. $)$ but the significant indirect effect of Shared Leadership $(b=-0.56 ; p<0.05)$ confirms the mediation. Bootstrapping results also supported that the indirect effect was significant because the CI (for 95 percent) was between - 1.06 and -0.06 , excluding zero. One inference from these results is that having a climate of participation allows the emergence of collective forms of leadership, thereby reducing turnover. 


\section{DISCUSSION}

One of the main concerns of organizations in the public sector is to guarantee its plural and democratic character, which can be facilitated by adopting decentralized processes of leadership (Huxham \& Vangen, 2005; Jesper \& Villadsen, 2010). However, empirical evidence on distributive and shared forms of leadership are still scarce, since most of the literature is built on theoretical research. Among the few empirical studies, almost all have focused on the direct effects of shared leadership, leaving the necessary conditions for its emergence out of the spotlight.

This article builds on and advances this stream of research by investigating the process involving three variables. Accurately, the model illustrates the importance of shared leadership in predicting turnover and examines the causal processes by which collective forms of leadership emerge. We found that a positive and safe participative climate contributes to the emergence of shared leadership in public schools, which, in turn, decreases turnover rates of public teachers. Indeed, since in a shared leadership context, the emergence of leaders occurs according to their capabilities and the group's needs, a favorable organizational climate is key to the emergence of this type of leadership (Bryant, 2003; Vries, 1999). Our findings support this perspective, showing that the existence of an organizational environment marked by trust, clear communication, support, and participation is a critical condition for shared leadership to prosper.

Furthermore, our findings provide empirical evidence of shared leadership effects on turnover, which reinforces the claims that the intent to leave an organization is also shaped by team structure and organizational factors (Conley \& You, 2018). While many organizational factors are relatively constrained, leaders, who share their power and involve their team in the decision-making process facilitate innovation and foster a sense of collaborative organizational climate that encourages individuals not to give up (DeWitt, 2017). This finding is particularly relevant since turnover rates have widespread effects on the school as a whole, directly impacting the motivation and commitment of those who stayed (Hom et al., 2017). Notwithstanding the potential benefits of collective forms of leadership, scholars must pay attention to how public leadership can contribute to greater realization, in practice, of important public values and greater creation of public value (Crosby \& Bryson, 2018).

Moreover, another interesting finding from our additional analysis is that participative safety does not have a direct relationship with turnover but operates through shared leadership. This indirect effect may highlight the importance of studying shared leadership in public organizations. Given that distributing leadership seems to aggregate team factors towards positive outcomes for the organization, models that explore only the direct effects of employee behaviors may fail to capture the importance of sharing leadership. Especially in public sector organizations, where a multiplicity of internal and external constraints leaves individuals with less control over their work, having the possibility to share responsibilities and decision making can significantly contribute to deal with the need for democratic deliberation and representation (Woods, 2005).

Indeed, leadership studies in the field of Public Administration have recognized the importance of shared processes of leadership. Sharing leadership roles not only reflects the democratic and plural nature of public management, but it also has a better fit with management styles based on collaborative governance (Ospina, 2017). Previous research on the topic has looked into management reforms that propose the dispersion of leadership (e.g., Currie et al., 2011; White et al., 2016). Such 
a stream of literature has acknowledged the positive effect of shared leadership in policy change and implementation, as well as its role in fostering citizen participation. They have also pointed out how management structures characterized by a concentration of power, bureaucracy and hierarchy can limit its effect (Currie \& Lockett, 2011; Ospina, 2017).

Our study looks at shared leadership from a different perspective. By focusing our analysis at schools, organizations that typically have flatter structures and lower power concentration, we were able to understand that not only organizational structures and management models affect the distribution of leadership, but also the climate fostered among individuals. We also look at a setting in which shared leadership is not part of a management reform program, but a process that emerges from the interaction among employees. Finally, different from previous research that has analyzed the impact of shared leadership on specific public policies, we have noticed how it has a direct effect on public management, as it increases the retention of personnel.

Despite the differences from previous literature on the topic, we believe that our findings complement the ones in previous works, offering a better understanding of the phenomena, and how it can be useful to the public context.

\section{CONTRIBUTIONS, LIMITATIONS AND FUTURE RESEARCH}

The current article serves to enhance public and shared leadership theories in several ways. First, we explored an organizational condition that enables shared leadership to emerge. Although previous studies conducted in the private sector have already shown the impact of environmental and team characteristics in the distribution of leadership (Lacerenza \& Salas, 2017; Wang, Waldman, \& Zhang, 2014), to our knowledge no research has empirically tested the effect of the preconditions for the emergence of plural leadership in the fields of public administration and education. Moreover, most of the empirical evidence regarding plural forms of leadership investigates its impact on variables, such as performance (e.g., Carson et al., 2007) and job satisfaction (e.g., Drescher \& Garbers, 2016). Nevertheless, observable indicators are less investigated. By exploring the effects of leadership on actual turnover, we contribute to the literature by providing evidence of the effects of shared leadership on objective indicators. Since leadership scholarship will only advance if much more attention is paid to developing and testing leadership theory and its impacts, we believe in having contributed to a better understanding of it.

Although research on leadership in the public sector has significantly grown in the last decade and clearly is a topic worthy of scholarly attention, most of the work is either theoretical or commonly adopts the case study methodology, limiting attention to explore causal mechanisms and cause-effect processes (Crosby \& Bryson, 2018). Since public leadership scholarship should move to a better understanding about how leaders and leadership can cause some positive change and stop some negative change (Crosby \& Bryson, 2018), another differential of our work is to investigate an input-process-output model, providing quantitative evidence of the positive effects of leadership in a public organization.

From a practical perspective, investigating turnover is relevant for all types of organizations, since it generates costs and impacts business productivity. Notwithstanding, different from the private sector, the public sector in Brazil has stability and tenure as issues that model servant's attitudes and hinder 
voluntary turnover (Oliveira \& Costa, 2019). In such a context, employee withdraw is still a more critical problem due to institutional constraints and red tape linked to hiring staff. Thus, we believe in contributing to the management practice by showing that sharing leadership responsibilities is an alternative to reduce voluntary turnover. Since we provided evidence on how the team and work environment characteristics favor the emergence of shared leadership, we contribute to add some insights that can be sought by organizations.

However, as distributed leadership is a process that results from interactions among individuals, our results show that organizations must have practices that foster a climate of collaboration and safety. By doing so, leadership will not only positively affect organizational results, but will also offer representativeness and democracy.

Notwithstanding the evidence provided by our study and the results obtained, they should be interpreted cautiously. First, the cross-sectional nature of the study limits any conclusions that can be made about causal relations between the antecedent and shared leadership. This is mainly due to collecting data at the same time. Our interpretation of causality is majorly based relies on the evidence of co-variation and our confidence in the proposed theoretical connections. Future research using longitudinal studies or multiple data collections could add to our proposed model.

A second limitation that must be mentioned is the measure of shared leadership. Measuring distributed forms of leadership has been a challenge both in the public and private settings. Literature indicates that social network analysis is the most suitable method for exploring shared forms of leadership, providing a better estimation than aggregating techniques (D'Innocenzo et al., 2014). However, it requires a minimum of $80 \%$ response rate (Carson et al., 2007). As we were unable to achieve this level of responses, we decided to adopt an aggregated measure of shared leadership yet developed to be used explicitly in educational settings.

Employee turnover is one of the most explored topics in the field of organizational behavior, as it not only affects organizational functioning, but it also indicates problems with engagement and job satisfaction (Hom et al., 2017). However, it is essential to acknowledge that other contextual and individual factors can drive the decision to leave the organization. Therefore, the relationship between shared leadership and turnover should be interpreted carefully.

Another potential limitation of our study is related to the control variables we used. Although we fully understand that individual characteristics and private interests can directly influence turnover, we analyzed the results at the organizational level, and thus, individual perspectives were not included in the model. Therefore, we suggest that future research should look into the impact of individual (such as age, gender, or tenure) and interpersonal variables (such as group diversity) on the emergence of shared leadership. Also, further works on the topic can take a multi-level perspective, taking into account variables at the individual and organizational levels simultaneously.

Bennett, Wise, Woods, and Harvey (2003) propose that not only a favorable organizational environment can impact shared leadership to emerge, but the presence of a formal leader that empowers and motivates the team would also work. We suggest that further research should investigate the effect of vertical leadership as a trigger or enhancer of the emergence of horizontal leadership, exploring different individual leadership styles, such as transformational or empowering leadership. 
RAP | Exploring shared leadership in public organizations: evidence from the educational arena

Despite the positive impact of shared leadership pointed out in this research, it is essential to acknowledge its limitations in the public context. As previously mentioned, collective processes of leadership usually emerge in knowledge-based organizations, with specialized personnel, that work independently in an integrated form (Kocolowski, 2010; Lacerenza \& Salas, 2017; Pearce, 2004). Therefore, such a process would be limited to some types of public organizations, such as hospitals, research institutes, schools, and universities.

Also, shared leadership usually emerges in organizations with horizontal structures, in which individuals can take part in the decision-making process (Pearce, 2004; Pearce \& Manz, 2005). Organizations with management models characterized by high levels of patrimonialism and bureaucracy might limit its flourishment.

Despite these limitations, as shared leadership can emerge in relevant public contexts, further studies on the topic are central research on Public Administration. Thus, we suggest that future work should investigate this phenomenon in other types of street-level bureaucracies that present conditions for its emergence. 


\section{REFERENCES}

Akbari, M., Kashani, S. H., \& Hooshmand Chaijani, M. (2016). Sharing, caring, and responsibility in higher education teams. Small Group Research, 47(5), 542-568.

Amabile, T.M. (1993). Motivational synergy: Toward new conceptualizations of intrinsic and extrinsic motivation in the workplace. Human resource management review, 3(3), 185-201.

Amestoy, S. C., Backes, V. M. S., de Lima Trindade, L., Ávila, V. C., de Oliveira, A. F.L., \& da Silva, C. N. (2014). Compreensão dos enfermeiros sobre o exercício da liderança no ambiente hospitalar. Cogitare Enfermagem, 19(3), 475-478.

Anderson, N., \& West, M. A. (1996). The team climate inventory: Development of the tci and its applications in teambuilding for innovativeness. European Journal of Work and Organizational Psychology, 5(1), 53-66.

Bagozzi, R. P., \& Yi, Y. (1988). On the evaluation of structural equation models. Journal of the Academy of Marketing Science, 16(1), 74-94.

Bennett, N., Wise, C., Woods, P., \& Harvey, J. A. (2003). Distributed Leadership: A Review of Literature. Nottingham, UK: National Clollege for School Leadership.

Bergman, J. Z., Rentsch, J. R., Small, E. E., Davenport, S. W., \& Bergman, S. M. (2012). The shared leadership process in decision-making teams. The Journal of social psychology, 152(1), 17-42.

Boies, K., Lvina, E., \& Martens, M. L. (2011). Shared leadership and team performance in a business strategy simulation. Journal of Personnel Psychology, 9(4), 195-202.

Bradley, B. H., Postlethwaite, B. E., Klotz, A. C., Hamdani, M. R., \& Brown, K. G. (2012). Reaping the benefits of task conflict in teams: The critical role of team psychological safety climate. Journal of Applied Psychology, 97(1), 151.

Braun, A. C., \& Fagundes, C. D. P. (2017). O desafio do enfermeiro frente à liderança compartilhada e colaborativa. Desenvolve Revista de Gestão do Unilasalle, 6(2), 113-126.

Bryant, M. (2003). Cross-cultural perspectives on school leadership: Themes from native American interviews. In N. Bennett, M. Crawford, \& M. Cartwright (Ed.), Effective Educational Leadership (pp. 216-228). London, UK: Sage.

Bullock, J. B., Stritch, J. M., \& Rainey, H. G. (2015). International comparison of public and private employees' work motives, attitudes, and perceived rewards. Public Administration Review, 75(3), 479489.

Carson, J. B., Tesluk, P. E., \& Marrone, J. A. (2007). Shared leadership in teams: An investigation of antecedent conditions and performance. Academy of Management Journal, 50(5), 1217-1234.

Chapman, C., Getha-Taylor, H., Holmes, M. H., Jacobson, W. S., Morse, R. S., \& Sowa, J. E. (2016). How public service leadership is studied: An examination of a quarter century of scholarship. Public Administration, 94(1), 111-128.

Conley, S., \& You, S. (2018). School organizational factors relating to teachers' intentions to leave: A mediator model. Current Psychology, 1-11.

Coelli, M., \& Green, D. A. (2012). Leadership effects: School principals and student outcomes. Economics of Education Review, 31(1), 92-109.

Crosby, B. C., \& Bryson, J. M. (2018). Why leadership of public leadership research matters: and what to do about it. Public Management Review, 20(9), 1265-1286.

Currie, G., \& Lockett, A. (2011). Distributing leadership in health and social care: concertive, conjoint or collective?. International Journal of Management Reviews, 13(3), 286-300.

Currie, G., Grubnic, S., \& Hodges, R. (2011). Leadership in public services networks: Antecedents, process and outcome. Public Administration, 89(2), 242-264.

Currie, G., Koteyko, N., \& Nerlich, B. (2009). The dynamics of professions and development of new roles in public services organizations: The case of modern matrons in the english NHS. Public Administration, 87(2), 295-311.

Currie, G., \& Lockett, A. (2007). A critique of transformational leadership: Moral, professional and contingent dimensions of leadership within public services organizations. Human Relations, 60(2), 341-370. 
Currie, G., Lockett, A., \& Suhomlinova, O. (2009). The institutionalization of distributed leadership: A "catch-22" in English public services. Human Relations, 62(11), 1735-1761.

D’Innocenzo, L., Mathieu, J. E., \& Kukenberger, M. R. (2016). A Meta-Analysis of Different Forms of Shared Leadership-Team Performance Relations. Journal of Management, 42(7), 1964-1991.

Dall'Agnol, C. M., de Moura, G. M. S. S., de Magalhães, A. M. M., Falk, M. L. R., de Oliveira Riboldi, C., \& de Oliveira, A. P. (2013). Motivações, contradições e ambiguidades na liderança de enfermeiros em cargo de chefia num hospital universitário. Revista Latino-Americana de Enfermagem, 21(5), 1172-1178.

Denis, J.-L., Langley, A., Sergi, V., Nationale, É., Publique, A., \& Montréal, H. (2012). The Academy of Management Annals Leadership in the Plural. The Academy of Management Annals, 6(1), 211-283.

Departamento Intersindical de Estatística e Estudos Socioeconômicos. (2018). Rendimento médio real trimestral dos assalariados do setor público e do setor privado. São Paulo, SP: Author.

DeWitt, P. M. (2017). School climate: Leading with collective efficacy. Thousand Oaks, CA: Corwin Press.

Drescher, G., \& Garbers, Y. (2016). Shared leadership and commonality: A policy-capturing study. The Leadership Quarterly, 27(2), 200-217.

Drescher, M. A., Korsgaard, M., Welpe, I. M., Picot, A., \& Wigand, R. T. (2014). The dynamics of shared leadership: Building trust and enhancing performance. Journal of Applied Psychology, 99(5), 771-783.

Fairchild, J., \& Hunter, S. T. (2014). "We've Got Creative Differences": The Effects of Task Conflict and Participative Safety on Team Creative Performance. The Journal of Creative Behavior, 48(1), 64-87.

Fausing, M. S., Joensson, T. S., Lewandowski, J., \& Bligh, M. (2015). Antecedents of shared leadership: empowering leadership and interdependence. Leadership \& Organization Development Journal, 36(3), 271-291.

Fitzgerald, L., Ferlie, E., McGivern, G., \& Buchanan, D. (2013). Distributed leadership patterns and service improvement: Evidence and argument from English healthcare. The Leadership Quarterly, 24(1), $227-239$
Fletcher, J., \& Kaufer, K. (2003). Shared Leadership: Paradox and Possibility. In C. L. Pearce, \& J. A. Conger (Ed.), Shared Leadership: Reframing the Hows and Whys of Leadership (1st ed., vol. 1). Thousand Oaks, CA: Sage Publications.

Fornell, C., \& Larcker, D. F. (1981). Evaluating structural equation models with unobservable variables and measurement error. Journal of Marketing Research, 18(1), 39-50.

Getha-Taylor, H., Holmes, M. H., Jacobson, W. S., Morse, R. S., \& Sowa, J. E. (2011). Focusing the public leadership lens: Research propositions and questions in the minnowbrook tradition. Journal of Public Administration Research and Theory, 21(1), 83-97.

Gumus, S., Bellibas, M. S., Esen, M., \& Gumus, E. (2018). A systematic review of studies on leadership models in educational research from 1980 to 2014. Educational Management Administration and Leadership, 46(1), 25-48.

Hair, J. F., Black, W. C., Babin, B. J., \& Anderson, R. E. (2010). Multivariate data analysis: A global perspective. London, UK: Pearson Education.

Hallinger, P. (2011). Leadership for learning: lessons from 40 years of empirical research. Journal of Educational Administration, 49(2), 125-142.

Hallinger, P., \& Heck, R. H. (2010). Collaborative leadership and school improvement: Understanding the impact on school capacity and student learning. School Leadership and Management, 30(2), 95-110.

Hom, P. W., Lee, T. W., Shaw, J. D., \& Hausknecht, J. P. (2017). One hundred years of employee turnover theory and research. Journal of Applied Psychology, 102(3), 530-545.

Huxham, C., \& Vangen, S. (2005). Managing to collaborate: the theory and practice of collaborative advantage. New York, NY: Routledge

Hvidman, U., \& Andersen, S. C. (2014). Impact of performance management in public and private organizations. Journal of Public Administration Research and Theory, 24(1), 35-58.

Jesper, R. H., \& Villadsen, A. R. (2010). Comparing public and private managers' leadership styles: Understanding the role of job context. International Public Management Journal, 13(3), 247-274. 
Klein, F. A., \& Mascarenhas, A. O. (2016). Motivação, satisfação profissional e evasão no serviço público: o caso da carreira de especialistas em Políticas Públicas e Gestão Governamental. Revista de Administração Pública, 50(1), 17-39.

Kocolowski, M. D. (2010). Shared leadership: Is it time for a change. Emerging Leadership Journeys, $3(1), 22-32$.

Kotter, J. P. (1990). How leadership differs from management. New York, NY: Free Press.

Lacerenza, C. N., \& Salas, E. (2017). The New Leader on the Block: A Review and Research Agenda of Shared Leadership. Academy of Management Proceedings, 1, 41 .

Leithwood, K., Mascall, B., Strauss, T., Sacks, R., Memon, N., \& Yashkina, A. (2007). Distributing leadership to make schools smarter: Taking the ego out of the system. Leadership and policy in schools, 6(1), 37-67.

Lima, L. C. (2014). A gestão democrática das escolas: do autogoverno à ascensão de uma pós-democracia gestionária?. Educação \& Sociedade, 35(129), 10671083.

Little, J. W. (1990). The persistence of privacy: Autonomy and initiative in teachers' professional relations. Teachers College Record, 91(4), 509-536.

MacBeath, J. (2005). Leadership as distributed: A matter of practice. School Leadership and Management, 25(4), 349-366.

Marks, M. A., Mathieu, J. E., \& Zaccaro, S. J. (2001). A temporally based framework and taxonomy of team processes. Academy of management review, 26(3), 356-376.

Mathieu, J., Maynard, M. T., Rapp, T., \& Gilson, L. (2008). Team effectiveness 1997-2007: A review of recent advancements and a glimpse into the future. Journal of management, 34(3), 410-476.

McGrath, J. E. (1964). Social Psychology: A Brief Introduction. New York, NY: Holt, Rinehart \& Winston.

Meier, K. J., \& O'Toole, L. J. (2011). Comparing public and private management: Theoretical expectations. Journal of Public Administration Research and Theory, 21(3), 283-299.
Mihalache, O. R., Jansen, J. J., Van den Bosch, F. A., \& Volberda, H. W. (2014). Top management team shared leadership and organizational ambidexterity: A moderated mediation framework. Strategic Entrepreneurship Journal, 8(2), 128-148.

O'Toole, L. J., \& Meier, K. J. (2015). Public management, context, and performance: In quest of a more general theory. Journal of Public Administration Research and Theory, 25(1), 237-256.

OECD. (2018). Education at a Glance 2018: OECD Indicators. Paris, France: OECD Publishing.

Ospina, S. M. (2017). Collective Leadership and Context in Public Administration: Bridging Public Leadership Research and Leadership Studies. Public Administration Review, 77(2), 275-287.

Passone, E. F. K. (2019). Gestão Escolar e Democracia: o que nos ensinam os estudos de Eficácia Escolar. Laplage em revista, 5(2), 142-156.

Park, S. M., \& Rainey, H. G. (2008). Leadership and public service motivation in U.S. federal agencies. International Public Management Journal, 11(1), 109-142.

Pearce, C. L. (2004). The future of leadership: Combining vertical and shared leadership to transform knowledge work. Academy of Management Executive, 18(1), 47-57.

Pearce, C. L. (2007). The future of leadership development: The importance of identity, multilevel approaches, self-leadership, physical fitness, shared leadership, networking, creativity, emotions, spirituality and on-boarding processes. Human Resource Management Review, 17(4), 355-359.

Pearce, C. L., \& Manz, C. C. (2005). The new silver bullets of leadership: The importance of self- and shared leadership in knowledge work. Organizational Dynamics, 34(2), 130-140.

Pearce, C. L., \& Conger, J. A. (2002). Shared leadership: Reframing the hows and whys ofleadership. London, UK: Sage.

Pearce, C. L., Wood, B. G., \& Wassenaar, C. L. (2018). The Future of Leadership in Public Universities: Is Shared Leadership the Answer? Public Administration Review, 78(4), 640-644.

Peci, A., Pieranti, O. P., \& Rodrigues, S. (2008). Governança e New Public Management: 
convergências e contradições no contexto brasileiro. Organizações \& Sociedade, 15(46), 39-55.

Peltokorpi, V., \& Hasu, M. (2014). How participative safety matters more in team innovation as team size increases. Journal of Business and Psychology, 29(1), 37-45.

Perry, J. L., \& Rainey, H. G. A. L. G. (1988). The Public-Private Distinction in Organization Theory: A Critique and Research Strategy. Academy of Management Review, 13(2), 182-201.

Raffel, J. (2007). Why has Public Administration Ignored Public Education, and Does it Matter? Public Administration Review, 67(1), 135-151.

Rainey, H. G. (2003). Understanding \& Managing Public Organizations. Nonprofit and Public Management Series. San Francisco, CA: Jossey Bass Publishers

Routhieaux, R. L. (2015). Shared leadership and its implications for nonprofit leadership. The Journal of Nonprofit Education and Leadership, 5(3), 139-152.

Secretaria Municipal de Educação da Cidade do Rio de Janeiro. (2017). Educação em Números. Retrieved from http://www.rio.rj.gov.br/web/sme/educacaoem-numeros

Sobral, F., \& Furtado, L. (2019). Post-heroic Leadership: Current trends and challenges in leadership education. Revista de Administração de Empresas, 59(3), 209-214.

Van Slyke, D. M., \& Alexander, R. W. (2006). Public service leadership: Opportunities for clarity and coherence. American Review of Public Administration, 36(4), 362-374.

Van Wart, M. (2011). PUBLIC SECTOR LEADERSHIP: INTERNATIONAL CHALLENGES AND PERSPECTIVES - edited by Jeffrey A. Raffel, Peter Leisink and Anthony E. Middlebrooks. Public Administration, 89(2), 714-717.

Van Wart, M. (2013). Lessons from Leadership Theory and the Contemporary Challenges of Leaders. Public Administration Review, 73(4), 553-565.

Vogel, R., \& Masal, D. (2015). Public Leadership: A review of the literature and framework for future research. Public Management Review, 17(8), 1165-1189.

De Vries, M. F. K. (1999). High-performance teams: Lessons from the pygmies. Organizational Dynamics, 27(3), 66-77.

Wahlstrom, K. L., \& Louis, K. S. (2008). How teachers experience principal leadership: The roles of professional community, trust, efficacy, and shared responsibility. Educational Administration Quarterly, 44(4), 458-495.

Wang, D., Waldman, D. A., \& Zhang, Z. (2014). A meta-analysis of shared leadership and team effectiveness. Journal of Applied Psychology, 99(2), 181-198.

White, L., Currie, G., \& Lockett, A. (2016). Pluralized leadership in complex organizations: Exploring the cross network effects between formal and informal leadership relations. Leadership Quarterly, 27(2), 280-297.

Woods, P. (2005). Democratic leadership in education. London, UK: Sage.

Wright, B.E., \& Pandey, S. K. (2010). Transformational leadership in the public sector: Does structure matter? Journal of Public Administration Research and Theory, 20(1), 75-89.

Wright, B. E., Pandey, S. K., \& Donald, P. M. (2012). Pulling the Levers: Transformational Leadership, Public Service Motivation, and Mission Valenc. Public Administration Review, 72, 206-215.

Yammarino, F. J., Salas, E., Serban, A., Shirreffs, K., \& Shuffler, M. L. (2012). Collectivistic Leadership Approaches : Putting the "We " in Leadership Science and Practice. Social for Industrial and Organizational Psychology, 5(4) 382-402.

Yukl, G. (2002). Leadership in Organizations (5th Ed.). London, UK: Pearson Education.

Zwick, E., Teixeira, M. P. D. R., Pereira, J. R., \& Vilas Boas, A. A. (2012). Administração pública tupiniquim: reflexões a partir da Teoria $\mathrm{N}$ e da Teoria P de Guerreiro Ramos. Cadernos EBAPE.BR, 10(2), 284-301. 


\section{Juliana Carvalho}

https://orcid.org/0000-0001-8434-7594

$\mathrm{PhD}$ student in Business Administration at the Brazilian School of Public and Business Administration at Fundação Getulio Vargas (FGV EBAPE). E-mail: juliana.carvalho.1@fgv.edu.br

\section{Filipe Sobral}

https://orcid.org/0000-0002-9900-9464

$\mathrm{PhD}$ in Business Management and Administration; Associate Professor at the Brazilian School of Public and Business Administration at Fundação Getulio Vargas (FGV EBAPE). E-mail: filipe.sobral@fgv.br

\section{Juliana Mansur}

https://orcid.org/0000-0002-7525-0691

$\mathrm{PhD}$ in Administration; Adjunct Professor at the Brazilian School of Public and Business Administration at Fundação Getulio Vargas (FGV EBAPE). E-mail: juliana.mansur@fgv.br 